\title{
RECURRENT SPONTANEOUS BREAST HEMATOMA: REPORT OF A CASE AND REVIEW OF THE LITERATURE
}

\author{
Marilu Stimamiglio Kanegusuku, Dirceu Rodrigues, Linei Augusta B. Dellê Urban, \\ Alexandre Bossmann Romanus, Rodrigo Peres Pimenta, Michelle Gusmão de Assis \\ and Karla Alessandra Ferrari
}

RHCFAP/3058

KANEGUSUKU MS et al. - Recurrent spontaneous breast hematoma: report of a case and review of the literature. Rev. Hosp. Clín. Fac. Med. S. Paulo 56(6):179-182, 2001.

Background: Breast hematomas are common after traumas, surgeries, or contusions. They are rarely spontaneous, but they can occur spontaneously in patients with hematologic disease or with coagulation disorders.

Material and methods: The authors report a clinical case of a 48-year-old female with a 27-year history of paroxysmal nocturnal hemoglobinuria who underwent mammography screening because of a painless palpable moveable node in the upper inner quadrant of the right breast.

Results: Mammography showed a partially defined heterogeneous node of $35 \mathrm{~mm}$ without microcalcifications in the upper inner quadrant of the right breast which, associated with the clinical features, seemed to be an hematoma. Further mammography and ultrasound after 45 days showed retrocession of the lesion, and another mammography obtained after 60 days was normal. Seventy-five days after the first episode, the patient complained of another node with a skin bruise in the upper outer quadrant of the same breast, which seemed to be a recurrent hematoma. Two months later the mammography obtained was normal.

Conclusion: Breast hematoma must be thought of as a differential diagnosis for a breast node, regardless of previous trauma or hematologic disorders.

DESCRIPTORS: Breast. Hematoma. Hematologic disease. Paroxysmal nocturnal hemoglobinuria.

Breast hematoma without a history of recent trauma is rare. It may be observed in patients having hematologic disease or other condition that causes thrombocytopenia or coagulation disorder, or it may occur in patients who take anticoagulant medication. The resultant edema of hemorrhage causes a palpable mass or a located dense image. It can simulate or hide a carcinoma, necessitating a complete investigation. The authors report a case of recurrent spontaneous breast hematoma in a 48-year-old patient with paroxysmal nocturnal hemoglobinuria (PNH).

\section{CASE REPORT}

A female patient, 48 years old, was being treated. She had a history of recurrent episodes of hemoglobinuria that needed blood transfusion since the age of 20. On routine clinical examination, a palpable node was found in the junction of the upper quadrant of the right breast, approximately $3.5 \mathrm{x}$ $3.0 \mathrm{~cm}$ in size, painless, moveable, and

From the Discipline of Radiology of the Federal University of Paraná. without nipple discharge or palpable axillary lymph node. Mammography showed a dense node image of $35 \mathrm{~mm}$ in the upper inner quadrant of the right breast with heterogeneous density, partially defined, and without microcalcifications. This lesion, associated with her clinical history, suggested a hematoma (Fig. 1). On that occasion, the hemogram had granulocytopenia and thrombocytopenia (white cells = $3300 / \mathrm{mm}^{3}$ and platelets $=38000 /$ $\mathrm{mm}^{3}$ ), and coagulation tests were normal. After 45 days the mammogram image showed substantial lesion re- 

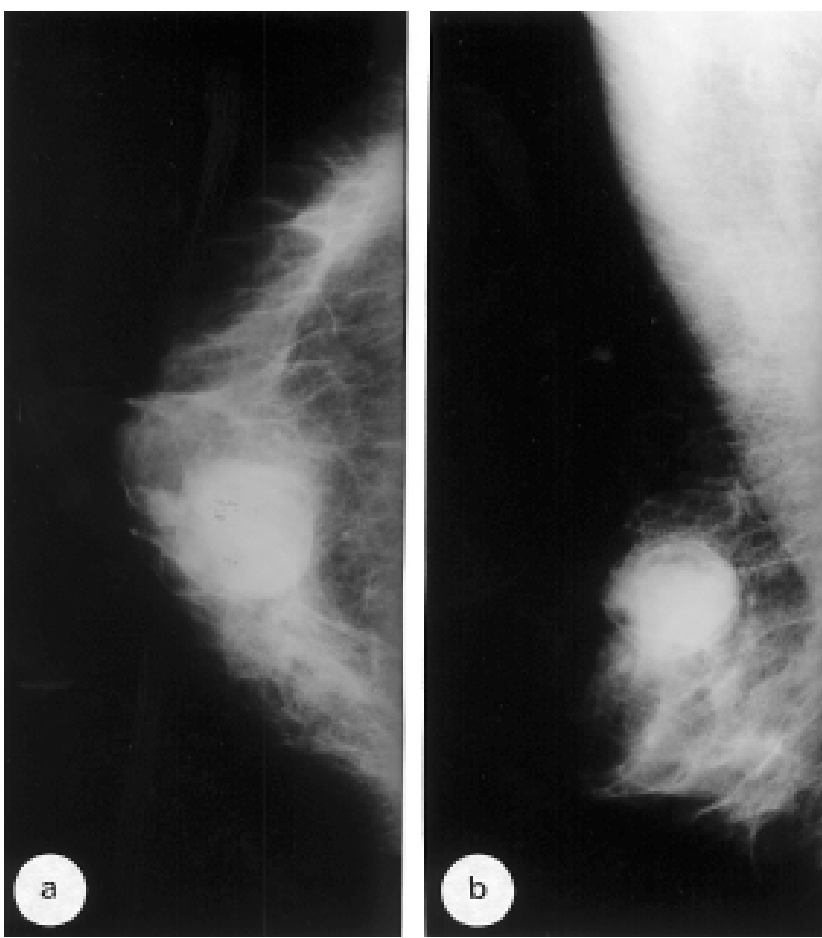

Figure 1 - Craniocaudal (a) and mediolateral (b) mammograms reveal a partially defined dense node.

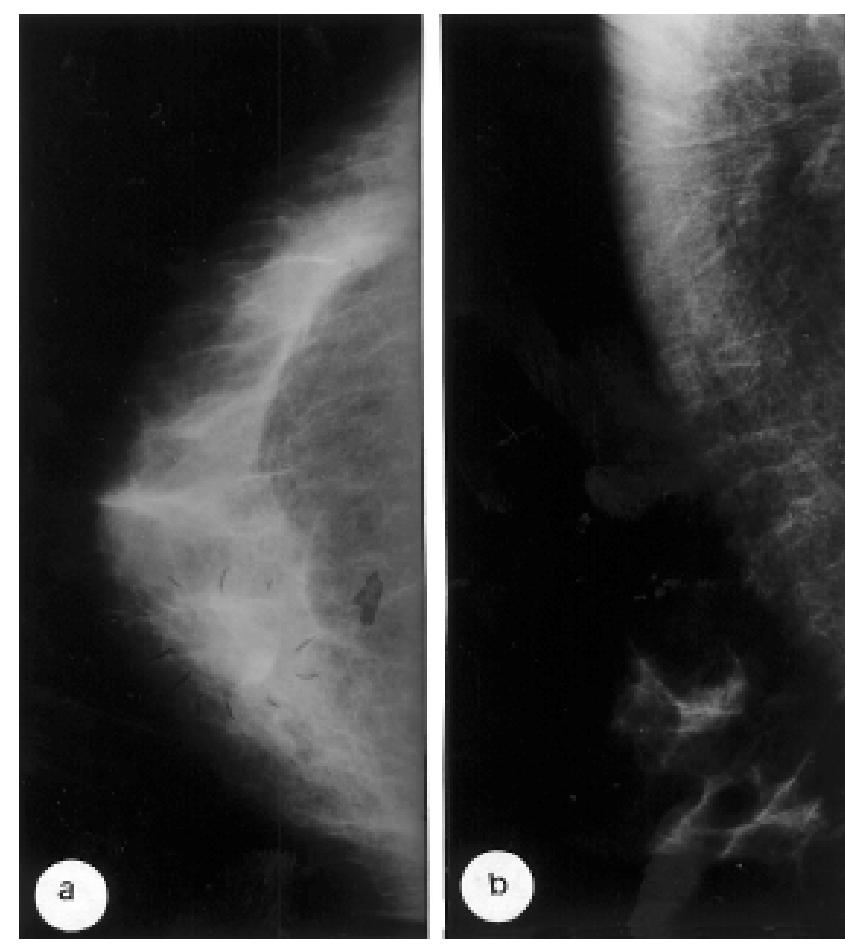

Figure 2 - Follow-up craniocaudal (a) and mediolateral (b) mammograms after 45 days showing partial regression of the lesion. gression, indicating only a tenuous area of greater density in the upper inner quadrant of the right breast; ultrasound showed a solid hyperechoic area of illdefined limits, $3.0 \times 1.7 \mathrm{~cm}$ in size, located in the parenchyma and progressing to the subcutaneous fat (Fig. 2). After 60 days, a new mammographic image showed no lesion (Fig. 3). Seventy-five days after the first episode of hematoma, the patient returned, presenting a new node in the same breast, palpable in the outer superior quadrant, $2 \times 2 \mathrm{~cm}$ in size, moveable, painless, and associated with a cutaneous hematoma. The hemogram showed similar values to the previous episode. Followup mammograms obtained 2 months after the second episode revealed no lesions in either breast.

\section{DISCUSSION}

Breast hematoma is the result of a hematic extravasation that diffusely infiltrates the mammary parenchyma and tends to form a focal collection. It usually occurs after trauma, contusion, surgery, or fine needle aspiration puncture. Breast hematoma also occurs rarely after a hemopathy. Our patient with a 27-year history of PHN had no history of spontaneous bleeding in other spots.

PHN is a rare acquired chronic hemolytic disorder characterized by a defect in the membranes of erythrocytes that makes them sensitive to the action of complement. It usually appears in the third or fourth decade of life, with the same incidence in both sexes. The beginning is insidious with progressive weakness and paleness, progressing to asymptomatic hemoglobinuria, or accompanied by lumbar pain during intense crises. The diagnosis is conducted by the presence of hepatolysin acid demonstrated by the HAM test or by a positive test of sugar water. There is no efficient treatment; therapy is directed only at the complications. Hemorrhagic disorders are rare and usually related to secondary

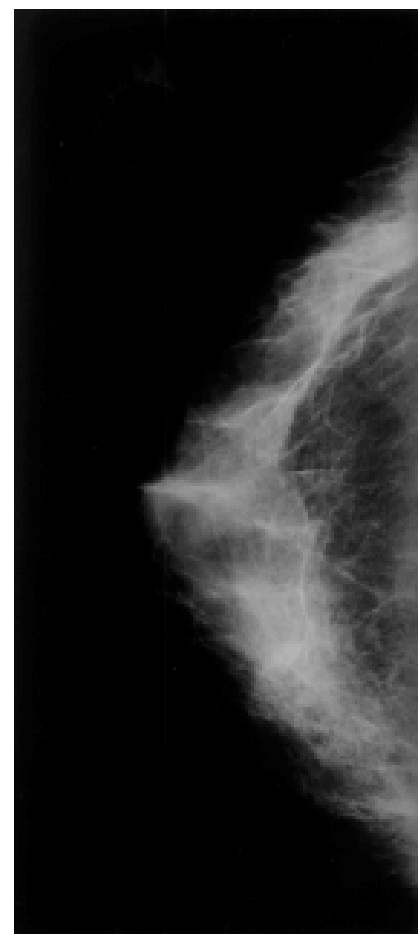

Figure 3 - Craniocaudal mammogram after 60 days showing complete regression of the lesion.

thrombocytopenia and bone marrow hypoplasia, which is usually fatal. No report was found of the association of 
breast hematoma and PHN in searches of MEDLINE (between 1976 and 2001) and LILACS (between 1982 and 2001) using the key words, breast hematoma, hematologic disease, and paroxysmal nocturnal hemoglobinuria.

On mammography, the hematoma appears as an asymmetric density associated with cutaneous thickness, or less frequently, as a nodular image with circumscribed margins. Sometimes the peripheral edema around the hematoma partially defines the lesion margins. Calcifications and spiculated margins are not present, even though in later stages, some hematomas may calcify. In $40 \%$ of the cases, no focal abnormality can be identified. Ultrasound is useful mainly in an early phase, when it demonstrates a very defined anechoic cyst. Ultrasound can also be used to monitor regression, where a mixture of cystic and solid compounds can be observed.

The most important differential diagnosis of breast hematoma is with carcinoma, because the mammographic appearance of asymmetric density and skin thickness is similar. Hemorrhage caused by an intracystic tumor also should be considered. Occult breast tumors were also reported as the cause of spontaneous bleeding in patients presenting coagulation disorders.

The majority of hematomas are monitored 4 to 6 weeks after initial observation until there is only a small focal distortion; it is necessary to keep the patient in observation until complete regression. In two situations, a biopsy is necessary for complete elucidation of the case: when there is absorption and the residual area presents a focal distortion of the parenchyma, or when there is not any absorption, in which the pa- tient has an organized hematoma that will always show mammographically as a mass of high density. Our patient, after 2 months of follow up, did not present any mammographic alterations, confirming the benign nature of the lesion, even though recurrent bleeding in the same breast occurred.

\section{CONCLUSION}

The diagnosis of hematoma must be considered in all patients who present a mammary node of sudden appearance and recent history of trauma. In patients with hemopathy or who are undergoing treatment with anticoagulant drugs, hematoma must be considered in the differential diagnosis of mammary nodes, even in the absence of a history of trauma.
KANEGUSUKU MS e col. - Hematoma espontâneo recorrente de mama: revisão da literatura e relato de caso. Rev. Hosp. Clín. Fac. Med. S. Paulo 56(6): 179-182, 2001.

Objetivo: Os hematomas de mama são comuns após traumatismo, cirurgias ou contusões. Raramente são espontâneos, podendo ocorrer em pacientes com doença hematológica ou outras doenças associadas a distúrbios da coagulação sangüínea.

Material e métodos: Os autores relatam o caso de paciente feminina, 48 anos, com diagnóstico e acompanhamento de Hemoglobinúria paro- xística noturna há 27 anos, submetida a mamografia por apresentar em consulta de rotina nódulo palpável em quadrante superior interno (QSI ) da mama direita, móvel e indolor.

Resultados: A mamografia evidenciou nódulo heterogêneo, de 35 $\mathrm{mm}$, em QSI da mama direita, de contorno parcialmente delimitado, sem microcalcificações, que correlacionado com a história clínica, sugeria o diagnóstico de hematoma. O controle evolutivo com mamografia e ecografia, após 45 dias mostrou substancial regressão da lesão e novo exame após 60 dias foi normal. Decorridos 75 dias do primeiro episódio, a paciente apresentou outro nódulo, agora associado a hematoma cutâneo, em quadrante superior externo da mesma mama, interpretado como novo hematoma. $\mathrm{O}$ controle clínico após dois meses do segundo episódio foi normal.

Conclusões: A hipótese de hematoma deve ser considerada no diagnóstico diferencial de nódulo mamário, com ou sem história de trauma ou doença sistêmica associada.

DESCRITORES: Mama. Hematoma. Doença hematológica. Hemoglobinúria paroxística noturna. 


\section{REFERENCES}

1. SHROTRIA S \& GHILCHIK MW - Breast haematomas: same appearance, different diagnosis. Br J Clin Pract 1994; 48:214215.

2. GOLLENTZ B, BALLARINI P, ROSSIER S et al. - Hematome et cytosteatonecrose mammaire: a propos of the 55 observations. J Radiol 1990; 71:33-43.

3. BESSLER M \& HILLMEN P - Somatic mutation and clonal selection in the pathogenesis and in the control of paroxysmal nocturnal hemoglobinuria. Sem Hematol 1998; 35:149-167.

4. IWANAGA M, FURUKAWA K, AMENOMORI T et al. - Paroxysmal nocturnal haemoglobinuria clones in patients with myelodysplastic syndromes. Br J Haemat 1998; 102:465-474.
5. PACKMAN CH - Pathogenesis and management of paroxysmal nocturnal hemoglobinuria. Blood Reviews 1998; 12:1-11.

6. MENDELSON EB - Evaluation of the postoperative breast. Radiol Clin North Am 1992; 30:107-138.

7. PAULUS DD - Benign diseases of the breast. Radiol Clin North Am, 1994; 21:27-50.

8. KUNI CC, WEISENSEE AM \& LE CK - Mammographic changes following conservation surgery and radiation therapy for breast cancer. Breast Dis, 1992; 5:69-81.

Received for publication on November 20, 2000 